\title{
The Impact of Corporate Governance Tools in the Reduction of Creative Accounting Practices in the Jordanian Commercial Banks
}

\author{
Prof. Khalil I. Al-Dulemi* \\ Irbid National University, Dept. Accounting \\ Issam Osama Ahmed Al-Shabatat \\ Irbid National University, Dept. Accounting
}

\subsection{Introduction}

In the past two decades, the world has witnessed an economic crisis and the collapse of major global companies. As example of these companies, the collapse of the US telecommunications company Worldcom in 2002, and the collapse of the largest energy companies in the United States, Enron, in 2001. The collapse of the worldrenowned auditing firm Arthur Anderson to prove its involvement in the collapse of Enron, where the reasons for the collapse of these companies were found to be the low ethics of professionals and their use by some of the accounting practices known as creative accounting practices in order to create imaginary improve in their financial statement. Therefore, it was necessary to use modern accounting systems for management and control to reduce the practices and methods of the creative accounting, and help to protect the capital and the interests of all parties through the activation of transparency and accountability, and one of these accounting systems known as corporate governance and its tools.

\subsection{Study problem}

The problem of the study focuses on the following main question:

Do corporate governance tools (Board of Directors, Audit Committees, Internal Audit, External Audit) have an impact on the reduction of creative accounting practices in Jordanian commercial banks.

\subsection{Objectives of the study}

1. Highlights the creative accounting and its practices.

2. Measuring the impact of corporate governance tools including the Board of Directors, Audit Committees, Internal Audit, and External Audit in reducing creative accounting practices in Jordanian commercial banks.

\subsection{The importance of the study}

The importance of this study is to demonstrate the role of corporate governance tools in reducing creative accounting practices in Jordanian commercial banks. This study is also important for Jordanian commercial banks as well as analysts, researchers and all parties dealing with Jordanian commercial banks, because it shows the impact of each tool of corporate governance tools in reducing creative accounting practices.

\subsection{Study Hypotheses}

The main hypothesis:

H0: Corporate governance tools have no impact on the reduction of creative accounting practices in Jordanian commercial banks. This hypothesis is divided from the following sub Hypotheses:

HO1: There is no statistically significant effect at the level of significance $(0.05 \geq a)$ of the Board of Directors in reducing creative accounting practices in Jordanian commercial banks.

HO2: There is no statistically significant effect at the level of significance $(0.05 \geq a)$ of the audit committees in limiting creative accounting practices in Jordanian commercial banks.

HO3: There is no statistically significant effect at the level of significance $(0.05 \geq$ a) for internal auditing in reducing creative accounting practices in Jordanian commercial banks.

HO4: There is no statistically significant effect at the level of significance $(0.05 \geq a)$ for external auditing in reducing creative accounting practices in Jordanian commercial banks.

\subsection{Previous studies}

First: Arabic Studies:

- (Ibrahim, Abdul Hussein, Baaj, 2017) entitled "Corporate governance and its role in reducing the methods of manipulation of creative accounting quality of financial reports in Iraqi banks"

This study aimed to identify the intellectual framework of corporate governance and mechanisms applied in Iraqi banks, and statement of the role of governance in reducing the manipulation of creative accounting with the 
quality of financial statement, and role statement of the Board of Directors in reducing the use of creative accounting practices in the Iraqi banking. The study found a set of results: that the practices of creative accounting are vary and depending on the purpose, circumstances and opportunities available to Iraqi banks for their practices and that there is a direct relationship between corporate governance and the quality of financial reports. This study has reached a set of recommendations which are: there must be extra work on further studies and researches on the application sound governance in Iraqi banks and their role in the reduction of administrative and financial corruption and creativity by banks for the purpose of the legal obligation to apply corporate governance.

- Ahmed, Mazmal, (2016), entitled "Role of Audit Committees in Limiting Profit Management Practices - Field Study"

The study aimed, primarily, to identify the role of audit committees in reducing the profit management practices by Sudanese banks departments to achieve self-benefits, and the questionnaire was distributed to the target of some workers in banks and offices of the review, the study found many of important results: there is an impact of Audit committees in reduce profit management practices. The study recommended the necessity of obligating Sudanese banks to form audit committees as a condition for inclusion in the Khartoum Stock Exchange.

\section{- (Fred, Amina, 2014) entitled "The Role of Corporate Governance Pillars in Reducing Creative}

Accounting Practices"

The aim of the study was to identify the role of corporate governance pillars of risk management, disclosure and control in reducing creative accounting practices. The study found that there are statistically significant indicators on the role of risk management and disclosure in reducing creative accounting practices, while there are no statistically significant indicators on the role of the control pillar in limiting these practices, due to the lack of separation of a significant number of sample companies studied between duties of the Board of Directors and CEO.

\section{Second: Foreign Studies:}

- (Tassadaq, Fizza, and Qaisar Ali Malik, 2015) entitled: "Creative Accounting and Financial Reporting: Model Development and Empirical Testing"

The study aimed to demonstrate the seriousness of creative accounting practices in the preparation of financial reports, the study pointed out that not only does creative accounting be seen as an ethical responsibility, but also to other factors affecting financial reports such as the role of auditors, the role of government regulations or international standards and the impact of exploitative behaviors And the impact of individual moral values. The study found several results, the most important one of them is that the company participates in fraud due to many factors such as unethical behavior, agency problem and non-professional attitudes. The study recommended implementing the corporate governance to limit these practices.

- (Vladu \& Cuzdriorean, 2013) titled "Creative Accounting, Measurement and Behavior"

The purpose of this research is to discuss creative accounting limitation through ethical developments, focusing on features as: measurement and behavior. In this respect we turn to an original search in the literature that comprise together estimation segment in accounting and theoretical developments from behavioral accounting, all with the scope of creating awareness regarding ethics role. After assessing the areas approached, our goal was further to discuss a possible development of a theoretical framework comprising cognitive structures. Important aspects of decision making process were approached and in correlation we discussed the implications that Machiavellian behavior, moral action model and cognitive moral development theory have upon creative accounting measurement and behavior. The originality of the paper consists in the manner we assess the ethics role as the "tone of the top" in the business sector and its implications to measurement and behavior in the area of creative accounting. The findings of our paper indicates that ethics as a solution used for limiting opportunistic behavior in accounting can have an unlimited potential as long term solution.

\section{- Odia \& Ogiedu, 2013, entitled "Corporate Governance, Regulatory Agency and Creative}

\section{Accounting Practices in Nigeria"}

This study deals with the impact of corporate governance and the regulatory activities of Nigerian Accounting Standards Boards (NASB) on creative accounting practices in Nigeria. A survey of the key players involved in financial reporting in Nigeria reveals that creative accounting practices exists in Nigeria. Using the linear regression analysis, it was found that both the corporate governance structure and the NASB's monitoring and enforcement of accounting standards have had insignificantly negative impact on creative accounting practices. Nevertheless the corporate governance tends to militate against creative accounting practices more than the policing by NASB. Therefore, it is recommended that the corporate governance mechanisms should be strengthened and the NASB should devise appropriate means and enlightenment, in addition to the sanctions and fines, for the elimination of creative accounting practices in Nigeria. 


\section{Theoretical framework}

In the theoretical framework, three topics will be addressed:

\subsection{The first topic: Creative accounting:}

\subsubsection{The Concept of Creative Accounting}

The concept of creative accounting has become a focus and attention by accountants and auditors very significantly in recent years, especially after the events of the collapse of Enron Corp. and hold Arthur Anderson being the company responsible for auditing the accounts of Enron Corp. is part of the responsibility for the collapse of The company accused of manipulating the financial statements of the company taking advantage of some treatments and accounting policies that show the financial statements in the wrong form.

Creative accounting has been defined as a set of tools and methods used to manipulate financial statements using a modern and innovative method by the administration for the purpose of manipulating the outcome of the activity, the statement of financial position and cash flow items in order to show the outcome of the economic unit activity in a manner that suits the wishes of the administration, Allowed by accounting principles and standards (Zayadi, Naim, 2015).

It has also been defined as " a set of accounting procedures used by corporate departments in some cases to seek an imaginary (unreal) improvement in either the outcome of their business or their financial position by exploiting gaps in external audit techniques or by taking advantage of the available alternatives In accounting policies that allow the entity's accounting standards to be followed in the areas of measurement and disclosure used in the preparation of financial statements, which adversely affects the quality of the figures shown by those statements, whether for profits or for the financial position and hence the credibility of financial ratios" (Matar, Mohamed, 2003).

Creative accounting is defined as the process of manipulating accounting figures by taking the opportunity to eliminate compliance with accounting rules, measurement alternatives, and disclosure applications for the transfer of financial statements, which must be to the preference of the author of such statements to report, In order to produce required accounting results, rather than to report such transactions in a fair and impartial manner. (Al-Khashawi and Al-Dosari, 2008)

It is also known as the use of new methods, ways, procedures, concepts, standards, or new theories that can be used to interpret, analyze or solve an accounting problem that faces the management, where the creative accountant has unique capabilities(Marzaka, Fatihah, 2010).

They were defined as unethical practices in the selection of estimates, and available accounting policies that allow for manipulation, and fraud resulting in incorrect and misleading financial data.

In the view of ( Youssef, Ibrahim, 2016) creative accounting is the methods used by who preparing the financial statements to manipulate accounting figures in order to achieve personal interests through the use of flexibility in accounting standards to choose between accounting rules and policies.

(Al-Khattab et al., 2012), described it as "the process of changing the accounting figures from the real form to the desired form to achieve the advantages of the company and its departments to disclose this information by choosing between the Alternatives of accounting policies or ignoring some of them."

(Web Dictionary, 2010) describes it as referring to the use of practices that deviate from standard or familiar accounting practices and is characterized by the use of modern, multiple and innovative methods and practices to obtain income smoothing, assets, liabilities and results of such practices that are complex and exciting in financial reporting That is why it was called creative. (http://www.bambooweb.com/articles/d/i/Dictionary:23/11/2010)

The researchers believe that creative accounting is a set of illegal practices, procedures and methods that are used to distort the financial statements and results of the actual work of the establishment, which the departments resort to achieve their own objectives and interests, without regard to the interests of other parties related to the facility.

\subsubsection{Creative accounting practices and Techniques}

There are many different types of account manipulation that vary from the emphasis on the selection and use of specific accounting methods, or the image of income to arrive at a predetermined or forecasted goal by the financial analyst, or to manipulate the financial statements by deliberately showing them to the contrary to mislead their authorized users on modern, complex and innovative practices to achieve conceptual goals.

Among the most important methods of creative accounting used in the financial statements are the following:

\section{A- Creative accounting methods used in the balance sheet (budget)}

The importance of the statement of financial position is shown by the information provided to its users about the assets, liabilities and true ownership of the enterprise. However, creative accounting methods can be used to manipulate this list and all its items, for example: (Al- Mukhaizem, 2008, p.16)

1- An overvaluation of intangible assets arising from mergers or a reduction in the amortization of assets over the applicable rates through an unjustified change in the depreciation method adopted at the entity. 
2- Non-disclosure of the assets of the entity.

3- Manipulate market prices when evaluating and classifying fixations.

4- Manipulation of inventory prices and the integration of inventories with stagnant and damaged goods.

5- Unjustified change in stock valuation methods.

6- The accounting recognition of the assets of the institution in contravention of the principles and rules stipulated in the international accounting standards.

7- Manipulation of exchange rates when transferring transactions to foreign currency and non- disclosure of monetary items of the institution.

B- Creative accounting practices used in the income statement:

The income statement helps to know the result of an organization's operation either profit or loss during a particular accounting period. However, the amount of net income can be manipulated by manipulating the value of revenues and expenses by: (Tanmli Suhair, 2006, p. 19)

1- Conduct fake sales transactions and include inventory statements for stagnant and damaged products.

2- Non-disclosure of changes in the organization, for example, the suspension of a production line with a

significant contribution to the outcome of the work of an entity.

3- Inclusion of exceptional extraordinary items within the operational result.

4- Unjustifiable change in accounting policies by moving current expenses to previous financial periods.

5- The transfer of current profits to later periods of the enterprise management's belief that it can be at a critical stage.

6- Inflated amounts of certain items under special arrangements and unjustified write-off of certain costs.

7- Set fake reserves to meet fake financial liabilities to maintain stable and fixed growth trend for profit.

$C$ - Creative accounting practices used in the cash flow statement:

The cash position of an entity is determined for a specific period of time through the cash flow statement. It represents the balance of cash flows received and through operating, financing and investing operations. The most important methods of manipulation are: (Al-Khashawi and Al- Dosari, 2008)

1- Misinformation in the classification of financing and investing and operating cash flows, and consider these practices do not affect final values.

2- Tax evasion by reducing the value of operational cash flows.

3- Recording fake income and outcome cash flows in various forms.

4- Trying to match the goals achieved with the predictions for great rewards and privileges.

D- Creative accounting methods used in the statement of changes in equity:

This statement shows the changes in private equity during a particular accounting period. However, all items in this statement are subject to the use of creative accounting practices, through the imaginary changes in capital increase or reduction, which are used to reevaluate the size of errors, losses of foreign exchange reserves or losses of market transactions finance.

From a moral perspective, these manipulations consider as immoral behavior because of the major irregularities that accountants follow in their profession to achieve immediate specific objectives for a particular category at the expense of the rest. Such practices must be addressed to obtain highly transparent and credible financial information. The role of auditors, the selection of efficient and credible audit firms, the development of a code of professional conduct, the reduction of the number of available alternatives and accounting treatments, the identification of the conditions under which each transaction may be used, the reduction of misuse of certain accounting policies, And other trends that support awareness and accounting culture. The International Accounting Standards Board of the International Federation of Accountants has made a significant contribution by introducing several amendments to accounting standards to avoid misuse of old standards and to eliminate innovative accounting practices that have emerged under the standards Old International Accounting.

\subsection{The second topic: Corporate Governance}

\subsubsection{The Concept of Corporate Governance}

The word (GOVERNANCE) is derived from the English word Governing (GOVERN), which means government, government. Thus, economists, analysts and experts agreed on the term "corporate governance", that is, corporate governance because of its economic, legal and social importance. Where corporate governance is the set of relationships that combine the executive management of the company with its board of directors, its shareholders and other stakeholders.

Governance is therefore a set of laws and decisions aimed at achieving quality and excellence in performance by selecting the appropriate and effective methods to achieve the objectives. In other words, governance means the existence of systems that govern performance-related interrelationships in order to preserve shareholders' rights, achieve fair treatment for them and strengthen the role of stakeholders. And the importance of disclosure and transparency, as well as confirm the responsibility of the Board of Directors.

The definitions presented by researchers on this term have varied according to their different perspectives. 
The IFC has defined governance as "the system by which companies are managed and controlled". Defined by the Organization for Economic Co-operation and Development (OECD) as "a set of relationships among corporate governance, board of directors, shareholders and other stakeholders".

As defined by Hammad Abdel-Al as: "the system through which the organization's work is directed and monitored at the highest level in order to achieve its objectives and meet the necessary standards of responsibility, integrity and openness.

In the same context, some focused on the most important principles of this system and the goals that they aspire to achieve. They define corporate governance as: "a set of tools, procedures, laws, systems and decisions that ensure both discipline, transparency and fairness, and thus aim to achieve quality and excellence in performance by activating the actions Management with regard to the exploitation of the economic resources available to it, so as to achieve the best possible benefits for all stakeholders and society as a whole "

The researcher believes that corporate governance is a set of rules, standards, tools, procedures, laws and regulations that define, govern and regulate the relationship between the management of an enterprise and shareholders, stakeholders and other parties associated with the enterprise.

\subsection{The relationship between corporate governance tools and creative accounting practices}

Corporate governance tools play a major role in reducing creative accounting practices, which naturally reflects the transparency of accounting disclosure and then presents accounting information fairly and more accurately in a way that serves the clients of enterprises and affects their various decisions. Reduction of Creative Accounting Practices:

1- Board of Directors

Is the highest authority in the company, which has all the necessary powers to take the decisions and procedures necessary to achieve the interest of shareholders who have given the Board the necessary authority, and the Board of Directors is the most important tools of governance, because it represents the top of the framework of corporate governance, consisting of independent members who come from outside the company. Thus, the primary function of the Board of Directors is to specifically and on behalf of investors to hold managers accountable and accountable for their performance to achieve the objectives of the institution and the interests of investors, thus limiting the interests of the private administration which are the reasons for the use of creative accounting methods, The Board of Directors implements the principles of corporate governance through these functions.

2-Audit Committees

Several studies in the area of corporate governance indicate the need for audit committees in the economic units that seek to implement corporate governance, and pointed out that the presence of audit committees is one of the main factors for evaluating the levels of institutional governance applied in economic units. The audit committees play a major role in quality assurance financial reporting and confidence in accounting information as a result of its oversight of internal and external audits and resistance to the pressures and interventions of the administration on the audit process. Moreover, the mere announcement of the economic unity of the formation of the Audit Committee The fact that has an impact on the movement of shares in the stock market.

It is important to conclude that one of the most important functions of the Audit Committees is to achieve transparency in accounting disclosure, increase the reliability of financial reporting quality and achieve confidence in accounting information as a result of its internal and external audit supervision, Institutional governance in achieving transparency and reliability in disclosure and limiting the creative accounting methods of manipulating financial statements and the outcome of an entity's business.

3-Internal Audit

Internal Audit is defined as an independent evaluation function within the organization, aimed at serving it by examining and evaluating its various activities. The objective of the internal audit is to assist the members of the organization in carrying out their responsibilities effectively by preparing analytical data and information, conducting studies; the internal audit was named because it is part of the internal administrative organization of the establishment (Aga, 2011).

Several studies in the area of corporate governance point to the need for internal audit committees to assist internal audit established to achieve their objectives, to confirm the effectiveness of internal controls and to work with the Board and the Audit Committee for risk management and control in the corporate governance process through evaluating and improving internal processes As well as the credibility and correctness of the accounting information disclosed by the entity as a result of the independence of the internal audit and its contact with the chairman of the audit committee. For accounting information that management can distort and manipulate through the use of creative accounting methods.

4-External Audit

External audit has a significant and effective role in the area of corporate governance as a result of the external auditor's confidence in and reliability of accounting information, by expressing his neutral technical opinion in 
the audit report on the validity and fairness of the financial statements prepared by the entity, In the financial statements that lead to misrepresentation and mislead its users by expressing its opinion on its validity and free of distortion and misleading if proven true, and to express his opinion if proven contrary (Aga, 2011).

The role of governance tools in the application of corporate governance principles and standards, the achievement and protection of the interests of all parties related to the enterprise, the quality of the enterprise's business, the credibility and validity of the accounting information disclosed by the entity, and the reduction and reduction of creative accounting practices Which is based on the realization of the specific interests of certain parties and manipulation of financial statements and accounts and the results of the business of the establishment

\section{Methodology of the study}

\subsection{The society and sample of the study}

The population for this study comprises Jordanian commercial banks listed on Amman Stock Exchange, according to the corporate directory from the official website of the Amman Stock Exchange, the 13 commercial banks until the end of the year 2015.

\subsection{Study variables}

This study aimed to verify the impact of corporate governance on the creative accounting in the Jordanian commercial banks practice tools, and therefore the study consisted of the following variables:

\subsubsection{The dependent variable: creative accounting practices}

It included the practice of Earnings management and income smoothing, each of which was measured as follows:

\section{1- Earnings management:}

Earnings management is measured using (Modified Jones Model (1995). When (Jean et al. (2004)) reported that it is the strongest among the models used to detect earning management, it is called in the optional dues method and to measure optional entitlements, the following steps are taken:

A. Measurement of total Accruals that can be measured by the cash flow method in which total receivables are calculated as the difference between net operating profit and cash flow from operating transaction through the following model:

$\mathrm{TACC}_{\mathrm{i}, \mathrm{t}}=\mathrm{ONI}_{\mathrm{i}, \mathrm{t}}-\mathrm{OCF}_{\mathrm{i}, \mathrm{t}}$

Whereas:

TACC $_{i, t}$ : Represents total bank Accruals (i) for period (t).

$\mathrm{ONI}_{\mathrm{i}, \mathrm{t}}$ : Represents the Bank's net operating profit (i) for the period $(\mathrm{t})$.

$\mathrm{OCF}_{\mathrm{i}, \mathrm{t}}$ : Represents cash flow from operating activities of the Bank (i) for the period ( $\mathrm{t}$ ).

B. A regression model that estimates the model coefficient by which Non-Discretionary Accruals (NDACC I, $t$ ) will be calculated by the following regression equation, which is performed for the group of sample banks each year separately.

$$
\frac{\mathrm{TA}_{\mathrm{i}, \mathrm{t}}}{\mathrm{A}(\mathrm{i}, \mathrm{t}-1)}=\propto_{1}\left(\mathrm{~A} \frac{1}{(\mathrm{i}, \mathrm{t}-1)}\right)+\propto_{2}\left[\frac{\Delta \mathrm{REV}_{\mathrm{i}, \mathrm{t}}-\Delta \mathrm{REC}_{\mathrm{i}, \mathrm{t}}}{\mathrm{A}(\mathrm{i}, \mathrm{t}-1)}\right]+\propto_{3}\left(\frac{\mathrm{PPE}_{\mathrm{i}, \mathrm{t}}}{\mathrm{A}(\mathrm{i}, \mathrm{t}-1)}\right)+\mathrm{e}_{\mathrm{i}, \mathrm{t}}
$$

$\mathrm{TA}_{\mathrm{i}, \mathrm{t}}:$ : Represents total Accruals of the bank (i) for period ( $\mathrm{t}$ ).

$\mathrm{A}_{(\mathrm{i}, \mathrm{t}-1)}:$ Represents Total assets of the Bank (i) for the period $(\mathrm{t})$.

$\triangle \mathrm{REV}_{\mathrm{i}, \mathrm{t}}$ : Change in revenue of the bank (i) for period $(\mathrm{t})$.

$\triangle \mathrm{REC}_{\mathrm{i}, \mathrm{t}}$ : Change in receivables of the Bank (i) for period ( $\mathrm{t}$ ).

$\mathrm{PPE}_{\mathrm{i}, \mathrm{t}}$ : Property, plant and Equipment of the bank (i) for period $(\mathrm{t})$.

$\mathrm{E}_{\mathrm{i}, \mathrm{t}}$ : The random error (residuals) represents the portion of total receivables that is not explained by regression model variables and is used as an indicator of discretionary accruals.

Estimating the parameters of the model $(\propto 1, \propto 2 ، \propto 3)$ Through which the calculation of discretionary accruals values.

C. Determination of Non-Discretionary Accruals is determined by the following regression equation, which is performed for the group of sample banks in each year separately.

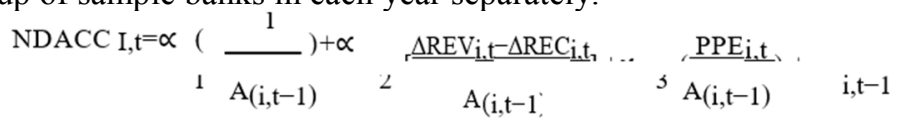

D. The discretionary accruals $\left(\mathrm{DACC}_{\mathrm{i}, \mathrm{t}}\right)$ for each bank are calculated by the difference between total accruals and non-discretionary accruals.

$\mathrm{DACC}_{\mathrm{i}, \mathrm{t}}=\mathrm{TACC}_{\mathrm{i}, \mathrm{t}}-\mathrm{NDACC}_{\mathrm{i}, \mathrm{t}} \ldots . .(4)$

E. Calculate the average number of discretionary accruals for each of the sample banks during the study years for the purpose of classifying them into practice and non-practice earning management banks.

Banks Classification: in practice and non-practice for earning management, the Bank shall exercise earning 
management if the value of its discretionary accruals per year is equal to or greater than the value of its average discretionary accruals. The Bank is not a profit management practitioner if its discretionary accruals for the year are less than the average value of its discretionary accruals and the absolute value of the bank's discretionary accruals during the study period was greater than the average of discretionary accruals. The bank exercises earning management, and if it is less than the average of its discretionary accruals, the bank does not exercise profit management.

2. Income smoothing: It measures the stability of accounting profits by minimizing the impact of future temporary fluctuations in profits and measured by calculating the standard deviation of net income to the standard deviation of the Bank's operating cash flows after dividing the two parties over total assets for the previous year according to the methodology used in the study (Francis et al., 2004) and according to the following model:

$\sigma(\mathrm{j}, \mathrm{t}) / T A \mathrm{j}, \mathrm{t}$

SMOOTH $\mathrm{j}, \mathrm{t}=$

$\sigma(\mathrm{j}, \mathrm{t}) / T A \mathrm{j}, \mathrm{t}$

Therefore, SMOOTH increases the quality of profits and the low value of SMOOTH indicates high profit quality. 3.2.2 Independent variables: Corporate Governance Tools

The Corporate governance tools, according to the corporate control manual in commercial banks, included the following tools:

1. The Board of Directors, including:

Board size: It has been measured by the number of Board members.

Board independence: It was measured by the percentage of external members to the total members of the Board. Ownership concentration: It was measured by the percentage of ownership of the Board of Directors which exceeds $5 \%$ of the total shares of the bank.

Duplication of duties: It was measured by $(0)$ in the absence of duplication (separation between the functions of the Executive Director and the membership of the Board of Directors) and No. (1) in case of duplication.

2. Audit Committee, including:

The size of the Audit Committee: It was measured by the number of members within the Audit Committee.

Number of meetings of the Audit Committee: It was measured by the number of annual Audit Committee meetings declared by the Bank.

3. Internal Audit: It was measured by the presence or absence of an internal audit department in Jordanian commercial banks.

The internal audit was excluded from the analysis and test that was measured by the existence of an audit department or lack of management, as it was found that all commercial banks in Jordan have an internal audit department and that all commercial banks ensure that the internal audit department performs its duties to the fullest extent efficiently and effectively.

External Audit: It was measured by the quality of the external audit, which indicates that the external audit office is linked to the international audit offices, which took the number (1) and the number (0) if the office is not connected to international offices.

\subsection{Statistical tools used}

E-Views software was used to process raw data where the following statistical measures and tests were used:

1. Percentages, frequencies, arithmetic averages and standard deviations, in order to describe the variables of the study.

2. Linear correlation coefficient for multicollinearity testing.

3. The Durbin-Watson test, to test the extent of the self-binding phenomenon.

4. Test the root of the Unit Root module, to determine the stability of time series

5. Analysis of simple and multiple linear regression to test the extent of the effect of independent variables on the dependent variable.

\subsection{Statistical analysis}

(4-1) the first topic: Description of the variables of the study

This chapter presents the descriptive statistics of the variables of the study independent and dependent, based on the annual financial statements of commercial banks listed in the Amman Stock Exchange and for the period 2010-2015.

\section{First: Description of dependent variables (the practice of creative accounting)}

The dependent variables included both earnings management practices and income smoothing. The results were as follows:

1. Earning Management (discretionary accruals) 
Table (1): The descriptive statistics of the absolute value of the discretionary accruals for the period (2010-2015)

\begin{tabular}{|l|l|}
\hline measurement & the absolute value of the discretionary accruals \\
\hline Arithmetic average & $93,699,410$ \\
\hline Standard deviation & $102,579,967$ \\
\hline maximum value & $555,125,992$ \\
\hline minimum value & $1,591,621$ \\
\hline
\end{tabular}

Table (1) presents a description of the annual discretionary accruals of the banks surveyed during the study period (2010-2015), where the annual arithmetic average reached JD (93.7) million, with a standard deviation of JD (102.6) million. , While the lowest value (1.6) million dinars. This shows that there is a wide variation in the quality of accruals for the banks surveyed, which may be due to the different reasons for the practices of creative accounting among Jordanian commercial banks.

Depending on the value of the discretionary accruals, it was determined whether commercial banks are considered an earnings management practice during the period. The following table provides a description of the profit management observations of the banks surveyed during the period.

Table (2): Earnings Management Views in Jordanian Commercial Banks during the Period (2010-2015)

\begin{tabular}{|l|l|l|l|}
\hline Variable & Group & Repetition & Percentage \\
\hline Earnings management & $\begin{array}{l}\text { non-practice of } \\
\text { management }\end{array}$ & $\begin{array}{l}\text { practice of earnings } \\
\text { management }\end{array}$ & 292.8 \\
\hline total & & $\mathbf{7 8}$ & 37.2 \\
\hline
\end{tabular}

The table shows that the number of observations of non-practice of earnings management activity reached (49) views, which represents $62.8 \%$ of the total views, while the number of observations of the practice of earnings management (29) and 37.2 This indicates that the practice of earning management is not a common phenomenon among Jordanian commercial banks, which may be due to the fact that commercial banks generally make annual profits and do not need much of this kind of creative accounting practices.

2- Income smoothing:

Table (3): Descriptive Statistics of Annual Income Smoothing Values for the Period (2010-2015)

\begin{tabular}{|l|l|}
\hline measurement & Income smoothing indicator \\
\hline Arithmetic average & 0.08 \\
\hline Standard deviation & 0.56 \\
\hline higher value & 2.31 \\
\hline lowest value & -2.43 \\
\hline
\end{tabular}

Table (3) presents a description of the annual income-smoothing values of the banks surveyed during the study period (2010-2015). The annual average of the calculation was 0.08 and the standard deviation was 0.56 . The highest value was 2.31 , lowest Value $(-2.31)$. This shows that there is a wide disparity in the practice of preparing the income of the surveyed banks. The increase in the value of the index indicates the practice of profit preparation and the low quality of profits. This may be due to different reasons and reasons for the exercise of creative accounting among Jordanian commercial banks.

\section{Second: Description of independent variables (Corporate Governance tools)}

Independent variables included the governance tools of the Board of Directors, Audit Committees and External Audit, and the results were as follows:

1. The Board of Directors

The Board of Directors has included the size of the Board, the concentration of ownership, the independence of the board, the duplication (separation between the position of Executive Director and membership of the Council). The results were as follows:

Table (4): descriptive statistics of the size of the Council, the independence of the Council, and the concentration of ownership for the period (2010-2015)

\begin{tabular}{|l|l|l|l|}
\hline measurement & $\begin{array}{l}\text { size of the Board } \\
\text { (member) }\end{array}$ & $\begin{array}{l}\text { concentration of } \\
\text { ownership\% }\end{array}$ & $\begin{array}{l}\text { Independence of the } \\
\text { board\% }\end{array}$ \\
\hline Arithmetic average & 10.83 & 51.83 & 82.40 \\
\hline Standard deviation & 1.71 & 26.16 & 15.16 \\
\hline higher value & 14 & 98.68 & 100 \\
\hline lowest value & 7 & 13.51 & 45.45 \\
\hline
\end{tabular}

From Table (4) above, we can see the following:

The size of the Board of Directors: The average number of members of the Board of Directors in the Jordanian commercial banks during the period 2010-2015 was 10.83 members with a standard deviation of 1.71 members. The largest viewing value was 14 members and the lowest viewing was 7 Members. 
Ownership Concentration: The average ownership of directors in Jordanian commercial banks during the period (2010-2015) was $51.83 \%$, with a standard deviation of $26.16 \%$, with the largest viewing percentage being $98.68 \%$, while the lowest share was $(13.51 \%)$.

Board of Directors' Independence: The average independence of the Board of Directors of Jordanian commercial banks during the period $2010-2015$ was $82.40 \%$, with a standard deviation $(15.16 \%)$. The largest viewing value $(100 \%)$ the lowest was $(45.45 \%)$.

The following table presents a description of the cases of duplication, where the frequency and homosexuality were based, and the results were as follows:

Table (5) Duplication Views of Jordanian Commercial Banks during the Period (2010-2015)

\begin{tabular}{|l|l|l|l|}
\hline variable & group & Duplication & percentage \\
\hline Duplication of tasks & There is a separation & 71 & 91.03 \\
\cline { 2 - 4 } & There is not a separation & 7 & 8.97 \\
\hline Total & & 78 & 100 \\
\hline
\end{tabular}

The number of observations of non-duplication (chapter) has reached (71) observations, which represent $(91.03 \%)$ of the total views, while the number of views of duplication (lack of separation) (7) Views, and by $(8.97 \%)$.

Based on the results of the two previous tables, we can conclude that Jordanian commercial banks generally adhere to the adoption and application of governance tools related to the Board of Directors.

2. Audit committees

Audit committees included the number of members of the Audit Committee and the number of annual meetings of the Committee. The results were as follows:

Table (6): Descriptive Statistics of the Audit Committees' Values for the Period (2010-2015)

\begin{tabular}{|l|l|l|}
\hline measurement & $\begin{array}{l}\text { \# of members of aduit } \\
\text { commitee }\end{array}$ & $\begin{array}{l}\text { \# of annual meetings } \\
\text { audit Committee }\end{array}$ \\
\hline Arithmetic average & 3.9 & 6.2 \\
\hline Standard deviation & 1.1 & 3.3 \\
\hline higher value & 8 & 16 \\
\hline lowest value & 3 & 2 \\
\hline
\end{tabular}

Note from Table (6) above, that:

The number of members of the Audit Committee: The average number of members of the Audit Committee of Jordanian commercial banks during the period (2010-2015), (3.9) members, by standard deviation (1.1) members, the value of the largest viewing (8) members, while the lowest viewing 3 Members.

The number of meetings of the Audit Committee: The average number of meetings of the Audit Committee in Jordanian commercial banks during the period (2010-2015) was (6.2) meetings, by standard deviation (3.3) meetings, the largest viewing was (16) meetings, 2) two meetings.

From the table above, we note that commercial banks converge among themselves in terms of the members of the Audit Committee and the number of annual meetings, depending on the standard deviation values, with a relatively uneven number of meetings.

3. External Audit

This variable was measured by the external auditor's engagement with global offices, the four largest (Deloitte, PricewaterhouseCoopers, Ernst \& Young, KPMG). The results were as follows:

Table (7): The external audit office's engagement with international offices in the Jordanian commercial banks during the period (2010-2015)

\begin{tabular}{|l|l|l|l|}
\hline Variable & group & Duplication & precentage \\
\hline External Audit & Linked to global offices & 70 & 89.7 \\
\cline { 2 - 4 } & Not linked to global offices & 8 & 10.3 \\
\hline total & & 78 & 100 \\
\hline
\end{tabular}

Table (7) shows that the number of observations of the audit office in global offices reached (70) observations, which represents $(89.7 \%)$ of the total views, while the number of views of the lack of engagement with international offices (8) (10.3\%). This indicates that Jordanian commercial banks generally assign external audit functions to international offices or local offices linked to international offices, which may be due to the increased experience of these offices in checking the banking operations.

\subsection{Testing hypotheses}

Main Hypothesis H0: There is no statistically significant impact of applying institutional governance tools to reducing creative accounting practices in Jordanian commercial banks.

The results of the hypothesis test are presented below:

The first hypothesis H01: There is no statistically significant effect at the level of $(0.05 \geq a)$ of the Board of 
Directors in limiting creative accounting practices in Jordanian commercial banks.

Table (8): Testing the Effect of the Board of Directors in Limiting Creative Accounting Practices in Jordanian Commercial Banks

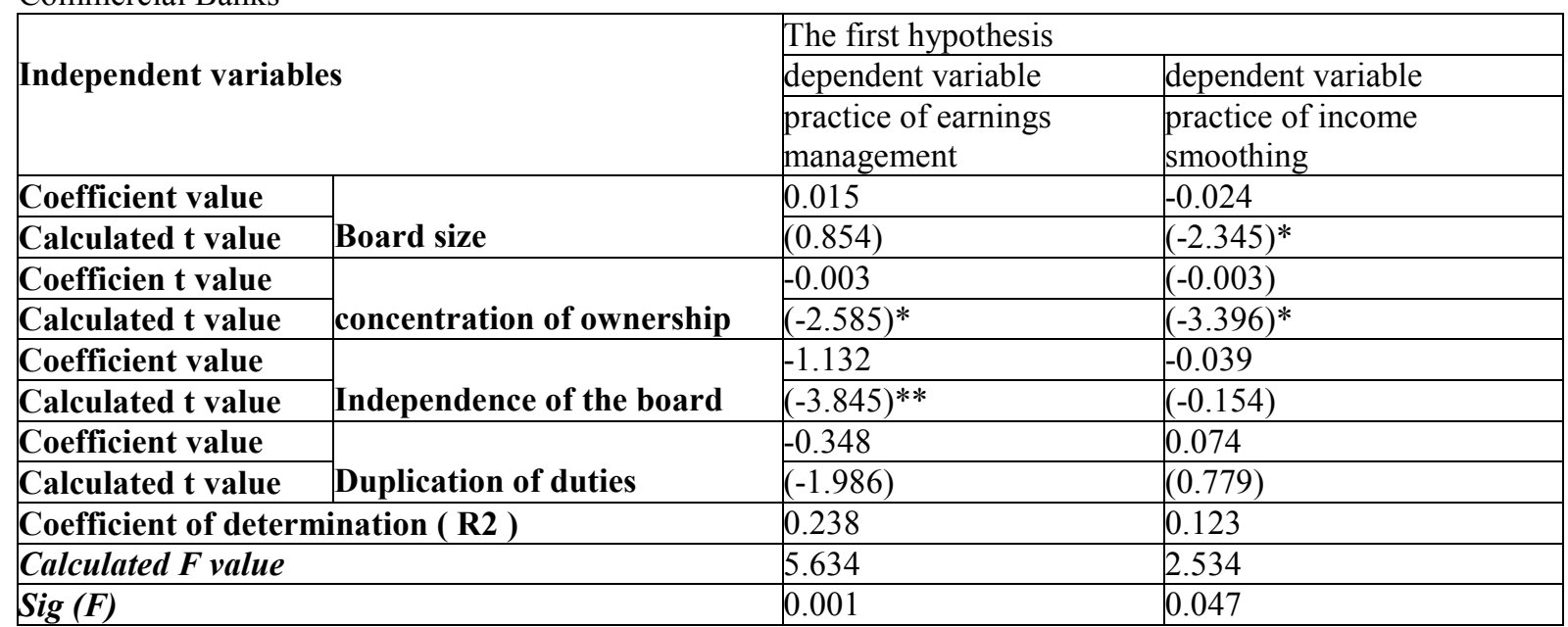

* $\mathrm{D}$ at the level of $0.05, * * \mathrm{D}$ at the level of 0.01 Note from Table (8) that:

The effect of the independent variables on the dependent variable (the practice of creative accounting) and the measure of earnigs management practice is statistically significant. The calculated $\mathrm{F}$ value is (5.634), and the significance level $(\mathrm{Sig}=0.001)$ is less than 0.05 , The Coefficient of determination value is $(\mathrm{R} 2=0.238)$ indicates that $23.8 \%$ of the variation in earnings management practice can be explained by the variation in the combined independent variables.

The table of coefficients showed that the value of the regression coefficient at the dimension (the size of the board) reached (0.015) and that the value of $t$ is 0.854 and a significance level greater than 0.05 indicating that the effect of this dimension is insignificant. The value of the coefficient at the time (concentration of ownership) is $(-0.003)$ and the value of $t$ is $(-2.585)$ and the significance level is less than 0.05 , indicating that the effect of this dimension is significant. The value of the coefficient at the end of the period (independence of the board) was $(-1.132)$ and the value of $t$ is $(-3.845)$, and a level of significance less than 0.01 , indicating that the effect of this dimension is significant. The value of the coefficient at the time (Duplication of tasks) was (- 0.348) and the value of $t$ is $(-1.986)$, with a significance level greater than 0.05 , indicating that the effect of this dimension is insignificant.

Based on the above, we reject the first null hypothesis and accept the alternative hypothesis that:

"There is a significant impact of the Board of Directors in reducing practices of creative accounting measured by practice of earnings management in Jordanian commercial banks"

2. The effect of the independent variables on the dependent variable (the practice of creative accounting) and the measurement of the income smoothing practice is statistically significant. The calculated $F$ value is $(2.534)$ and the significance level $(\mathrm{Sig}=0.047)$ is less than 0.05 , $(\mathrm{R} 2=0.123)$. It indicates that $12.3 \%$ of the variation in the practice of income smoothing can be explained by the variation in the combined independent variables.

The table of coefficients showed that the value of the regression coefficient at a distance $(-0.024)$ and that the value of $t$ is $(-2.345)$ and a level of significance less than 0.05 , indicating that the effect of this dimension is significant. The value of the coefficient at the end (concentration of ownership) is (-0.003) and the value of $t$ is (3.396) and the significance level is less than 0.05 , indicating that the effect of this dimension is significant. The value of the coefficient at the end of the period (independence of the board) reached (-0.039) and its value $t$ ($0.154)$, with a significance level greater than 0.05 , indicating that the effect of this dimension is insignificant. The value of the coefficient at the post (Duplication of tasks) was (0.074) and the value of $t$ is $(0.779)$, with a significance level greater than 0.05 , indicating that the effect of this dimension is insignificant.

Based on the above, we reject the first null hypothesis and accept the alternative hypothesis that:

"There is a significant impact of the Board of Directors in reducing practices of creative accounting measured by the practice of smoothing of income in Jordanian commercial banks"

The second hypothesis H02: There is no statistically significant effect at the level of ( $0.05 \geq a)$ of the Audit Committee in limiting creative accounting practices in Jordanian commercial banks. 
Table (9): Testing the effect of the Audit Committee on creative accounting practices in Jordanian commercial banks

\begin{tabular}{|c|c|c|c|}
\hline & & The first hypothesis & \\
\hline Independent varia & & dependent variable & dependent variable \\
\hline Coefficient value & Audit committee size & 0.006 & -0045 \\
\hline Calculated t value & & $(3.933) * *$ & $(-1.461)$ \\
\hline Coefficient value & & -0.002 & 0.007 \\
\hline Calculated t value & Audit committee & $(-3.482) * *$ & $(0.917)$ \\
\hline Calculated t value & & 0.146 & 0.037 \\
\hline Coefficient of dete & ation ( R2 ) & 6.386 & 1.453 \\
\hline Calculated F value & & 0.003 & 0.240 \\
\hline Sig (F) & & 0.006 & -0.045 \\
\hline
\end{tabular}

* D at level $0.05, * * \mathrm{D}$ at level 0.01 Note from table (9) that:

The effect of the independent variables on the dependent variable (the practice of creative accounting) and the measure of earnings management practice is statistically significant. The calculated $\mathrm{F}$ value is (6.386) with the significance level $(\mathrm{Sig}=0.003)$ is less than 0.05 , the value of the coefficient of determination $(\mathrm{R} 2=0.146)$ indicates that $14.6 \%$ of the variation in profit management practice can be explained by the variation in the combined independent variables.

The table of coefficients showed that the value of the regression coefficient at a distance (the size of the audit committee) reached (0.006) and that the value of $t$ is (3.933) and a level of significance less than 0.01 , indicating that the effect of this dimension is significant. The value of the coefficient at the end of the meeting (the meetings of the Audit Committee) is (-0.002) and the value of $t$ is (-3.482) and the level of significance is less than 0.01 , indicating that the effect of this dimension is significant.

Based on the above, we reject the second null hypothesis and accept the alternative hypothesis that:

"There is a significant statistical impact of the Audit Committee in reducing practices of creative accounting measured by the practice of earnings management in Jordanian commercial banks"

2. The effect of the independent variables on the dependent variable (the practice of creative accounting) and the measured by income smoothing practice is statistically significant. The calculated $F$ value is (1.453) and the significance level $(\mathrm{Sig}=0.240)$, which is greater than 0.05 , the value of the coefficient of determination $(\mathrm{R} 2=$ $0.037)$ indicates that $(3.7 \%)$ of the variation in the practice of the income smoothing can be explained by the variation in the independent variables combined.

The table of coefficients showed that the value of the regression coefficient at a distance (the size of the Audit Committee) reached (-0.045) and that the value of $t$ is (-1.461) and a significance level greater than 0.05 , indicating that the effect of this dimension is insignificant. The value of the coefficient at a distance of the meeting (the meetings of the Audit Committee) reached (0.007) and the value of $t$ is $(0.017)$, with a significance level greater than 0.05 , indicating that the effect of this dimension is insignificant.

Based on the above, we accept the second null hypothesis:

"There is no statistically significant impact of the Audit Committee on the reduction of practices of creative accounting measured by the practice of income smoothing in Jordanian commercial banks"

The third hypothesis H03: There is no statistically significant effect at the level of significance $(0.05 \geq a)$ for the external audit in limiting creative accounting practices in Jordanian commercial banks.

Table (10): Testing the Effect of External Audit on Limiting Creative Accounting Practices in Jordanian Commercial Banks

\begin{tabular}{|c|c|c|}
\hline \multirow[t]{3}{*}{ Independent variables } & \multicolumn{2}{|l|}{ The first hypothesis } \\
\hline & dependent variable & dependent variable \\
\hline & $\begin{array}{l}\text { practice of earnings } \\
\text { management }\end{array}$ & $\begin{array}{l}\text { practice of income } \\
\text { smoothing }\end{array}$ \\
\hline \multirow[t]{2}{*}{ Quality of external audit } & 0.167 & -0.622 \\
\hline & $(1.019)$ & $(-3.995) * *$ \\
\hline Coefficient of determination ( R2 ) & 0.013 & 0.174 \\
\hline Calculated F value & 1.037 & 15.959 \\
\hline Sig $(F)$ & 0.312 & 0.000 \\
\hline
\end{tabular}

$* \mathrm{D}$ at level $0.05, * * \mathrm{D}$ at level 0.01 Note from Table (10) that:

The effect of the independent variable (quality of external audit) on the dependent variable (the practice of creative accounting) and the measure of profit management practice is statistically insignificant, where the calculated $\mathrm{F}$ value is $(1.037)$, and the significance level $(\mathrm{Sig}=0.312) 0.05$, where the value of the coefficient of 
determination $(\mathrm{R} 2=0.013)$ indicates that $(1.3 \%)$ of the variation in profit management practice can be explained by variance in the independent variable.

2 The table of coefficients showed that the value of the regression coefficient at the distance (quality of the external audit) reached (0.167) and that the value of $t$ is (1.019) and a significance level greater than 0.05 , indicating that the effect of this dimension is insignificant.

Based on the above, we accept the third null hypothesis:

"There is no statistically significant impact of external auditing in reducing practices of creative accounting measured by earnings management in Jordanian commercial banks"

3. The effect of the independent variable (external audit) on the dependent variable (the practice of creative accounting), measured by the practice of income smoothing, is statistically significant. The calculated $\mathrm{F}$ value is $(15.959)$ and the significance level $(\mathrm{Sig}=0.000)(\mathrm{R} 2=0.174)$. It indicates that $17.4 \%$ of the variation in the practice of income-generation exercise can be explained by variance in the independent variable.

The table of coefficients showed that the value of the regression coefficient at the distance (the quality of the external audit) was (-0.622) and that the value of $t$ is $(-3.995)$ and the level of significance is less than 0.01 , indicating that the effect of this dimension is significant.

Based on the above, we reject the third null hypothesis and accept the alternative:

"There is a statistically significant impact of the external audit in reducing practices of creative accounting measured by practice of income smoothing in Jordanian commercial banks"

To test the main hypothesis of the study, multiple regression analysis was used, and the results were as follows:

Table (11): Testing the Effect of Corporate Governance Instruments on Reducing Creative Accounting Practices in Jordanian Commercial Banks

\begin{tabular}{|c|c|c|c|}
\hline & \multicolumn{2}{|l|}{ The first hypothesis } \\
\hline \multicolumn{2}{|c|}{ Independent variables } & dependent variable & dependent variable \\
\hline Coefficient value & \multirow[b]{2}{*}{ Board size } & 0.136 & -0022 \\
\hline Calculated t value & & $(1.725)$ & $(-1.229)$ \\
\hline Coefficient value & \multirow[b]{2}{*}{ concentration of ownership } & -0.020 & -0.006 \\
\hline Calculated t value & & $(-5.189) * *$ & $(-3.460) * *$ \\
\hline Coefficient value & \multirow[b]{2}{*}{ Independence of the board } & -2.226 & -0.639 \\
\hline Calculated t value & & $(-2.611)^{*}$ & $(-1.920)$ \\
\hline Coefficient value & \multirow[b]{2}{*}{ Duplication of tasks } & -1.067 & 0.206 \\
\hline Calculated t value & & $(-1.918)$ & $(0.268)$ \\
\hline Coefficient value & \multirow[b]{2}{*}{ Audit committee size } & 0.043 & 0.067 \\
\hline Calculated t value & & $(0.460)$ & $(2.029) *$ \\
\hline Coefficient value & \multirow[b]{2}{*}{ Audit committee } & -0.069 & 0.006 \\
\hline Calculated t value & & $(-2.211)^{*}$ & $(0.658)$ \\
\hline Coefficient value & \multirow[b]{2}{*}{ Quality of external audit } & -0.645 & -0.498 \\
\hline Calculated t value & & $(-2.995) * *$ & $(-3.898) * *$ \\
\hline \multicolumn{2}{|c|}{ Coefficient of determination ( R2 ) } & 0.347 & 0.187 \\
\hline \multicolumn{2}{|l|}{ Calculated F value } & 5.233 & 3.446 \\
\hline \multicolumn{2}{|l|}{$\operatorname{Sig}(F)$} & 0.000 & 0.021 \\
\hline
\end{tabular}

$* \mathrm{D}$ at level $0.05, * * \mathrm{D}$ at level 0.01 Notes from Table (11) that:

1. The effect of the independent variables on the dependent variable (the practice of creative accounting) and the measure of earnings management practice is statistically significant. The calculated $F$ value is (5.233) and the level of significance $(\mathrm{Sig}=0.000)$ is less than 0.05 , the value of the coefficient of determination $(\mathrm{R} 2=$ 0.347 ) indicates that $34.7 \%$ of the variation in earnings management practice can be explained by the variation in the combined independent variables.

The table of coefficients showed that the value of the regression coefficient at the dimension (the size of the board) reached (0.136) and that the value of $t$ is $(1.725)$ and a significance level greater than 0.05 , indicating that the effect of this dimension is insignificant. The value of the coefficient at the post (concentration of ownership) was $(-0.020)$ and the value of $t$ is $(-5,189)$ and the level of significance is less than 0.01 , indicating that the effect of this dimension is significant. The value of the coefficient at (independence of the board) (-2.226) and its value $t(-2.611)$ and a level of significance less than 0.05, indicating that the effect of this dimension is significant. The value of the coefficient at the post (Duplication of tasks) was $(-1.067)$ and the value of $t$ is $(-1.918)$, with a significance level greater than 0.05 , indicating that the effect of this dimension is insignificant. The value of the coefficient at the end (the size of the Audit Committee) reached (0.043) and the value of $t$ is $(0.460)$ and the significance level greater than 0.05 , indicating that the effect of this dimension is insignificant. The value of the 
coefficient at (Audit Committee meetings) (-0.069) and its value $t(-2.211)$, with a significance level less than 0.05 , indicating that the effect of this dimension is significant. The value of the coefficient at the end (quality of the external audit) was $(-0.645)$ and the value of $t$ is $(-2,995)$ and a level of significance less than 0.01 , indicating that the effect of this dimension is significant.

Based on the above, we reject the main null hypothesis and accept the alternative hypothesis that:

"There is a statistically significant impact of the tools of corporate governance in reducing the practices of creative accounting measured by practice of earnings management in Jordanian commercial banks"

2. The effect of the independent variables on the dependent variable (the practice of creative accounting) and the measurement of the income smoothing practice is statistically significant. The calculated $\mathrm{F}$ value is (3.446) and the significance level ( $\mathrm{Sig}=0.021)$ is less than $0.05,(\mathrm{R} 2=0.187)$. It indicates that $18.7 \%$ of the variation in the practice of income-smoothing can be explained by the variation in the combined independent variables.

The table of coefficients showed that the value of the regression coefficient at a distance $(-0.022)$ and that the value of $t$ is $(-1.229)$, with a significance level greater than 0.05 , indicating that the effect of this dimension is insignificant. The value of the coefficient at the end (concentration of ownership) is (-0.006) and the value of $t$ is $(-3.460)$ and the level of significance is less than 0.01, indicating that the effect of this dimension is significant. The value of the coefficient at (independence) of the council (-0.639) and its value $t(-1.920)$, with a significance level greater than 0.05 , indicating that the effect of this dimension is insignificant. The value of the coefficient at the time (Duplication of tasks) was 0.206 and the value of $t$ is 0.268 and a significance level greater than 0.05 indicating that the effect of this dimension is insignificant. The value of the coefficient at the end (the size of the Audit Committee) reached (0.067) and the value of $t$ is (2.029) and the level of significance less than 0.05, indicating that the effect of this dimension is significant. The value of the coefficient at the time of (Audit Committee meetings) (0.006) and its value $t(0.658)$, with a significance level greater than 0.05 , indicating that the effect of this dimension is insignificant. The value of the coefficient at the end of (external audit quality) was $(-0.498)$ and the value of $t$ is $(-3.898)$ and a level of significance less than 0.01 , indicating that the effect of this dimension is significant.

Based on the above, we reject the main nihilistic hypothesis and accept the alternative hypothesis that:

"There is a statistically significant impact on the tools of governance in reducing the practice of creative accounting measured by the exercise of the introduction of income in Jordanian commercial banks"

\section{Conclusions and Recommendations}

\subsection{Conclusions}

Based on the analysis of the study data and the hypothesis test, the study reached the following results:

1. The results of the main hypothesis test showed a statistically significant effect of the tools of corporate governance on practices of creative accounting, measured by the practice of earnings management in Jordanian commercial banks. The results of the sub-hypothesis test showed a statistically significant effect on the characteristics of both the Board of Directors and the Audit Committee on the practice of creative accounting, as measured by the practice of earnings management in Jordanian commercial banks. The results showed no statistically significant effect of external auditing on the practice of creative accounting, measured by the practice of earnings management in Jordanian commercial banks.

2. The results of the main hypothesis test showed that there is a statistically significant impact on the tools of governance on practices of creative accounting measured by the practice of income smoothing in Jordanian commercial banks. The results of the sub-hypotheses test showed a statistically significant effect on both the characteristics of the Board of Directors and the quality of external auditing on practices of creative accounting, measured by the practice of income smoothing in Jordanian commercial banks. While the results showed that there is no statistically significant effect on the characteristics of the Audit Committee on practices of creative accounting measured by the practice of income smoothing in Jordanian commercial banks.

3. All commercial banks in Jordan have an internal audit department. All commercial banks ensure that the Bank's internal audit department performs its functions effectively and efficiently. This helps in the proper application of the rules and principles of corporate governance and the reduction of accounting practices. Creative.

4. The results showed that there is a clear difference between banks in terms of the practice of the method of income smoothing. This may be due to the Bank's desire to maximize the rate of growth in income and to build a positive image of the Bank's performance which contributes to the satisfaction of shareholders, to the bank by stabilizing income.

5. The difference between the number of cases of commercial banks that are not used to manage profits and the practice of this method, and a large difference between them $(25.6 \%)$ for non- practicing banks during the period (2010-2015). This difference is due to the fact that commercial banks in general earn annual profits, it does not need much of this kind of creative accounting 
practices. It is well aware of the risks of earnings management because it deals with depositors' funds and a very large leverage because of the size of deposits compared to its capital. The most significant risk is the impact on the credibility of the financial statements and their lack of Objectivity and credibility, which negatively affects the decisions of users of those financial statements.

\subsection{Recommendations}

Based on conclusions of the study, it recommends the following:

1. Raising the awareness of the Jordanian commercial banks management about the negative consequences and risks of adopting creative accounting practices and their impact on the performance of banks through holding workshops and conferences for stakeholders, including investors.

2. Activating the supervisory role, and imposing controls and accounting determinants in a manner that hinders the ability of banks to exploit their flexibility gaps to manipulate the declared profits, limiting the ability of the management to achieve its own objectives at the expense of stakeholders.

3. Extensive search for standards designed to detect creative accounting practices.

4. To urge the committees of auditing the Jordanian commercial banks to hold periodic meetings on a regular basis, in order to increase the level of communication between the members of the committees and the concerned parties, and address all matters related to the bank.

5. Expanding future studies on the impact of corporate governance tools on the practice of creative accounting by addressing other variables and sectors.

\section{References}

\section{Arabic References}

Aga, E., S.(2011) The Role of Corporate Governance in Reducing the Negative Impact of Creative Accounting on the Reliability of Financial Data, Master of Accounting, Faculty of Economics and Administrative Sciences, Al-Azhar University, Gaza.

Ahmed, M. (2016), The Role of Audit Committees in Limiting Profit Management Practices - A Field Study, Neelain University Journal, Volume 5, Issue 19.

Al- Tanmli, S. (2006), Analytical Study of the Responsibility of the Auditor on Innovative Practices, Journal of Financial and Commercial Studies, Faculty of Commerce, Beni Suef University, Egypt.

Al-Mukhaizeem, U. (2008), The role of the auditor in verifying the practices and results of creative accounting, the ninth research competition at all levels of the Audit Bureau, Kuwait.

Darwish, K. (2007), Internal Audit and Functions, p64.

Farid, A. F., (2014), Role of Corporate Governance Pillars in Reducing Accounting Practices, PhD thesis, Baji Mukhtar University-Annaba.

Ibrahim, Abdul Hussain, Al-Baaj, (2017), Corporate Governance and its Role in Reducing the Methods of Manipulation of Creative Accounting in the Quality of Financial Reports in Iraqi Banks, Al-Nilain University Journal, Issue 28.

Khashawi R., and Al-Dosari, A. (2008), Role of the Auditor in Limiting the Effects of Using Creative Accounting in the Preparation of the Financial Statements, Sixth Research Competition at All Accounting Divisions, Kuwait.

Khattab, M, S., and Yasser A., (2012), a proposed framework for activating corporate governance in the extraction of some methods of creative accounting, Journal of Public Administration, No. 2, p218-219.

Khoury, A. ( 2003), Accounting Profession between Financial Impairment and Institutional Control in Companies, Al Bayan Newspaper, Rabi 'Al Awwal, May 25, United Arab Emirates.

Marzaka, F. (2010), Accounting Innovation through International Accounting Standards, Saad Dahlab University, Blida, Algeria.

Matar, M. (2003), Role of Disclosure of Accounting Information in Strengthening and Activating Institutional Control, 5th Professional Scientific Conference of the Association of Chartered Accountants of Jordan, Amman, 24-25 September 2003.

Youssef, I. (2016), The Effect of Fair Value Accounting on Creative Accounting - A Field Study, Neelain University Journal, Volume 5, Issue 20.

Zayadi, N. (2015), The Effect of Creative Accounting Methods on the Reliability of Financial Statements, Qadisiyah Journal of Administrative and Economic Sciences, Volume 17, Issue 2.

Foreign References:

Hudaib, R. \& Zaman, S. (2001 ,The Corporate Governance Effects of Audit Committees, Journal of Management and Governance 8 (3).

Odia, E. \& Ogiedu, T. (2013), Corporate Governance Regulatory Agency and Creative Accounting Practices in Nigeria, Mediterranean Journal of Social Sciences MCSER Publishing, Vol.4, No.3. 
Tassadaq, F. and Malik, Q. A. .(2015) " Creative Accounting and Financial Reporting: Model Development and Empirical Testing", International Journal of Economics and Financial Issues, vol 5 no.2.

Vladu, C. (2013), Creative Accounting, Measurement and Behavior, Annales Universitatis Apulensis Series Oeconomica, 15(1), 107-115. www.OECD.org 